\title{
Konfirmasi Empat Faktor yang Berpengaruh terhadap Word of Mouth di Rumah Sakit
}

\author{
Fajar Saputra \\ Program Program Studi Diploma III Administrasi Rumah Sakit \\ Sekolah Tinggi Ilmu Kesehatan Indonesia Maju \\ Jln. Harapan Nomor 50. Lenteng Agung-Jakarta Selatan 12610, Telp : (021) 78894045 \\ Email: fajar.saputra1988@gmail.com
}

\begin{abstract}
Abstrak
Pemasaran merupakan salah satu masalah bagi setiap rumah sakit atau organisasi pelayanan kesehatan lainnya. Kurang berhasilnya pemasaran diantaranya akibat kurangnya rumah sakit berpihak pada kepentingan pasien. Tujuan penelitian ini untuk mengatahui pengaruh langsung dan tidak langsung serta besarannya Pencitraan Rumah Sakit, Keputusan Menggunakan Jasa, Kualitas Jasa dan Kepuasan Pasien, Terhadap word of mouth di RSDH Cianjur. Metode dalam penelitian ini yakni dengan menggunakan pendekatan kuantitatif yang menggunakan cross sectional. Sampel yang digunakan sebanyak 80 Pasien sebagai responden. Metode analisis yang digunakan adalah structural equation model (SEM) menggunakan SmartPLS dan SPPS. Hasil pengujian hipotesis ditemuan pada penelitian pengaruh langsung dari pencitraan rumah sakit (16,73\%), Keputusan menggunakan jasa (26,36\%), kualitas jasa (I2,58\%), kepuasan (26,32\%). pengaruh langsung word of mouth $81,99 \%$ sedangkan pengaruh tidak langsung sebesar I,54\% serta pengaruh langsung dan pengaruh tidak langsung sebesar 83,53\%. Kepuasan faktor yang sangat dominan mempengaruhi word of mouth. Semakin pasien merasa puas maka akan semakin positif pula rekomendasi word of mouth. Saran penelitian ini bagi bagian marketing RSDH Cianjur agar melakukan promosi pelayanan kesehatan melalui media massa seperti televisi, radio dan brosur, mengingat promosi merupakan indikator pencitraan rumah sakit yang paling berpengaruh terhadap peningkatan word of mouth.
\end{abstract}

Kata kunci : Pencitraan, Keputusan, Kualitas, Kepuasan, WOM

\begin{abstract}
Marketing is one of the problems for every hospital or other health service organization. The lack of success in marketing includes the lack of hospitals in favor of the interests of patients. The purpose of this study was to find out the direct and indirect effects and magnitude of Hospital Imaging, Decision to Use Services, Service Quality and Patient Satisfaction, Against Word of Mouth in Cianjur Hospital. The method in this study is by using a quantitative approach that uses cross sectional. The sample used was 80 patients as respondents. The analysis method used is structural equation model (SEM) using SmartPLS and SPPS. The results of testing the hypothesis found in the study of the direct effect of hospital imaging (I6.73\%), decision to use services (26.36\%), service quality (I $2.58 \%)$, satisfaction (26.32\%). direct influence of word of mouth $81.99 \%$ while indirect effect is $1.54 \%$ and direct influence and indirect effect is $83.53 \%$. Satisfaction of very dominant factors influences word of mouth. The more patient feels satisfied, the more positive the word of mouth recommendations will be. The suggestion of this research is for Cianjur Hospital to conduct health service promotion through mass media such as television, radio and brochures, considering that promotion is a hospital imaging indicator that has the most influence on increasing word of mount.
\end{abstract}

Keywords : Imaging, Decision, Quality, Satisfaction, WOM 


\section{Pendahuluan}

Pemasaran merupakan salah satu masalah bagi setiap rumah sakit atau organisasi pelayanan kesehatan lainnya. Kurang berhasilnya pemasaran diantaranya akibat kurangnya rumah sakit berpihak pada kepentingan pasien. Karena apa yang telah disampaikan saat dipasarkan seringkali tidak sesuai dengan apa yang didapatkan pasien, dan ini tentunya akan menimbulkan image yang tidak baik untuk rumah sakit tersebut. Rumah sakit perlu mendesain program pemasaran agar produk mendapat respon dari pasar sasaran. Karena itu perlu alat supaya program tersebut mencapai sasaran. Alat disini adalah program yang bisa dikontrol oleh organisasi, alat tersebut lazim disebut bauran pemasaran (marketing mix). ${ }^{1}$

Kemampuan rumah sakit untuk menarik dan mempertahankan pasien baru merupakan sebuah fungsi yang tidak berasal dari produk atau pelayanan itu sendiri, namun juga berkaitan dengan bagaimana organisasi tersebut melayani pasien dan reputasi yang diciptakan oleh rumah sakit, baik di dalam maupun di luar rumah sakit. Mencari pasien baru lebih sulit dan memerlukan biaya lebih mahal dibandingkan bila mempertahankan pasien lama. Loyalitas pasien akan menjadi kunci sukses, tidak hanya dalam jangka pendek, tetapi keunggulan bersaing yang berkelanjutan. $^{3}$

Menurut The Jay H. Baker word of mouth menunjukkan bahwa konsumen yang tidak puas sangat berbahaya. Studi ini menemukan, $31 \%$ konsumen yang tidak puas memberi tahu orang lain, kemudian $6 \%$ dari jumlah tersebut menyebarkannya kepada 6 orang atau lebih. Diperkirakan, dari 100 konsumen yang tidak puas,maka akan kehilangan 32-36 konsumen atau calon konsumen word of mouth yang negatif. $^{4}$

Berdasarkan penelitian yang dilakukan Onbee Marketing kepada 2000 konsumen di lima kota besar Indonesia diketahui bahwa 89\% konsumen Indonesia lebih mempercayai rekomendasi dari teman dan keluarga pada saat memutuskan untuk membeli sebuah produk. Sementara itu, iklan hanya menempati peringkat kelima sebagai sumber referensi yang dipercaya oleh pasien ${ }^{5}$

Promosi paling efektif justru melalui word of mouth. Pelanggan yang terpuaskan akan menjadi juru bicara produk anda secara lebih efektif dan meyakinkan ketimbang iklan jenis apapun. Kepuasan semacam itu mustahil terjadi tanpa servis yang prima.

Pelayanan kesehatan adalah pelayanan jasa, jasa berbeda dengan barang. Jika barang merupakan suatu obyek, benda atau alat, maka jasa adalah suatu perbuatan, kinerja (perfomance). Seseorang tidak dapat menilai hasil dari jasa sebelum ia menikmatinya sendiri. Mereka akan meyimpulkan kualitas jasa dari tempat (place), orang (people), peralatan (equipment), bahan-bahan komunikasi (communication materials), simbol, harga yang mereka amati.

Salah satu cara utama membedakan pelayanan jasa kesehatan termasuk pelayanan rawat jalan adalah memberikan jasa pelayanan kesehatan yang berkualitas, lebih tinggi dari pesaing secara konsisten. Kuncinya adalah memenuhi atau melebihi harapan pasien tentang mutu pelayanan yang diterimanya. Setelah menerima jasa pelayanan kesehatan, pasien akan membandingkan jasa yang dialami dengan jasa yang diharapkan.

Jika jasa yang dirasakan tidak sesuai dengan jasa yang diharapkan, maka pasien tidak puas dan akhirnya tidak akan loyal kepada rumah sakit. Namun jika jasa yang dirasakan memenuhi atau bahkan melebihi harapan pasien maka pasien akan puas dan tetap bersedia menjalin hubungan jangka panjang dengan rumah sakit serta menjadi pasien yang loyal kepada rumah sakit. ${ }^{6}$

Perubahan orientasi jasa pelayanan kesehatan menyebabkan terjadinya persaingan antar rumah sakit dalam meningkatkan jumlah pemakai jasa rumah sakit. 
Persaingan ini memaksa pihak manajemen harus membuat suatu konsep rencana pemasaran yang berorientasi kepada konsumen bagi rumah sakit yang dikelolanya sehingga rumah sakit tersebut mempunyai suatu keunggulan yang dapat dipergunakan untuk menghadapi persaingan. Berbagai strategi yang relevan sesuai dengan karakteristik produk/jasa dilakukan oleh rumah sakit misalnya saja dengan memberikan produk yang mutunya lebih baik, harganya lebih murah, pengantaran dan penyerahan produknya lebih cepat, pelayanannya lebih baik, bila dibandingkan dengan apa yang diperbuat oleh pesaingnya. Apabila hal itu terjadi sebaliknya, yaitu produk dengan mutu yang jelek, harganya mahal, pengantaran produknya lambat, pelayanannya seenaknya, maka keadaan ini pasti memberikan ketidakpuasan bagi pelanggan.

Jasa pelayanan kesehatan seperti rumah sakit, klinik sebagai institusi yang padat modal dan sumber daya manusia, membutuhkan budaya perusahaan yang baik agar sumber daya yang tersedia dimanfaatkan secara efektif dan efisien untuk mencapai tujuan yang telah ditetapkan. Pada masa mendatang, kunci utama kesuksesan rumah sakit terletak pada dua hal pokok yaitu pemanfaatan sumber daya khususnya SDM secara efektif dan efisien, dan kepuasan pemakai jasa rumah sakit tersebut (pasien dan keluarga). Sejalan dengan perkembangan dan persaingan rumah sakit yang ada, pada akhirnya kepuasan pelanggan saja tidak cukup. Hal ini karena kualitas pelayanan yang baik dari rumah sakit akan menciptakan kepuasan pada pemakai jasanya. Adanya loyalitas pelanggan akan menguntungkan pihak rumah sakit apalagi pasien mau menceritakan pengalamannya selama di rumah sakit tersebut kepada pihak lain (word of mouth communication). ${ }^{7}$

Kualitas layanan merupakan salah satu faktor kunci bagi keberhasilan perusahaan dan tidak dapat dipungkiri dalam dunia bisnis saat ini, karena tidak ada yang lebih penting bagi suatu perusahaan kecuali menempatkan masalah kepuasan pelanggan melalui pelayanan yang berkualitas sebagai salah satu komitmen bisnisnya $^{8}$

Belakangan para pelaku usaha dituntut untuk berusaha lebih karena iklim persaingan semakin keras, namun kemampuan ekonomi masyarakat terus menurun. Untuk itu para pelaku usaha perlu melakukan usaha pemasaran yang baik. Yang dimaksud dengan pemasaran itu sendiri adalah proses merencanakan konsepsi, harga, promosi dan distribusi ide, menetapkan peluang yang dapat memuaskan individu dan sesuai dengan tujuan organisasi. Salah satu bentuk pemasaran yang dapat dilakukan adalah dengan melakukan word of mouth communication (Kotler, 2003). ${ }^{9}$

Kepuasan pasien merupakan salah satu upaya untuk menciptakan hubungan yang baik antara rumah sakit dengan pelanggan. Pasien yang memperoleh produk atau jasa yang sesui atau melebihi harapan, cenderung akan memberikan tanggapan yang positif bagi perusahaan. Salah satunya adalah melakukan komunikasi word of mouth kepada rekanrekannya. Word of mouth communication adalah salah satu cara yang efektif untuk membangun citra positif bagi rumah sakit, selain itu WOM juga dapat meningkatkan jumlah kunjungan pasien dan penjualan jasa rumah sakit. ${ }^{10}$

Sebuah proses pengambilan keputusan tidak hanya berakhir dengan terjadinya transaksi pembelian, akan tetapi diikuti pula oleh tahap perilaku purnabeli (terutama dalam pengambilan keputusan yang luas). Dalam tahap ini konsumen merasakan tingkat kepuasan dan ketidakpuasan tertentu yang akan mempengaruhi perilaku berikutnya. Jika konsumen merasa puas, ia akan memperlihatkan peluang besar untuk melakukan pembelian ulang atau membeli produk lain diperusahaan yang sama dimasa yang akan datang. ${ }^{11}$

Pelanggan yang puas dengan pelayanan, dan menyebarkan pandangan 
positif yang membantu penyedia layanan kesehatan mendapatkan pasien baru tanpa biaya tambahan, pada dasarnya adalah komunikasi word of mouth. Komunikasi word of mouth (WOM) adalah komunikasi secara lisan dari orang ke orang dalam bentuk komunikasi antara penerima dan komunikator, mengenai merek, produk atau jasa. Sebaliknya, WOM berbeda dari iklan, karena WOM terdiri dari pertukaran pesan lisan atau diucapkan saja serta adanya manfaat antara sumber yang berdekatan dengan penerima yang berkomunikasi . ${ }^{12}$

Menurut Chengiz dan Yaila, pentingnya word of mouth sebagai media pemasaran adalah bahwa karena word of mouth selalu relevan dan tepat waktu, dan hal itu didorong oleh kebutuhan pelanggan dan tumbuh secara eksponensial, misalnya, salah satu menceritakan sebuah cerita untuk lima orang, mereka masing-masing kirim ke lima lagi, yang mengatakan untuk lima lebih setelah itu. word of mouth juga memanfaatkan sifat manusia, dimana pada kenyataan bahwa banyak orang suka untuk menganggap dirinya ahli setidaknya dalam menilai sesuatu. ${ }^{13}$

Kualitas pelayanan dalam unit-unit retail adalah sangat penting untuk memuaskan pelanggan, mempertahankannya serta menciptakan loyalitas di antara pelanggan. Penelitian ini menggunakan SERVQUAL untuk menganalisis kesenjangan antara persepsi dan harapan pelanggan, mengenai dengan layanan pada unit ritel di negara bagian India Selatan Andhra Pradesh.

Tingkat Kepuasan Pelanggan dinilai untuk layanan yang ditawarkan pada unit ritel tertentu di kota Hyderabad. Lima dimensi kualitas layanan (servqual), tangibility, reliability, responsiveness, emphaty, dan jaminan telah dipertimbangkan dalam penelitian empiris tersebut. Tujuan umum dari penelitian tersebut adalah untuk mengetahui beberapa faktor yang mempengaruhi kepuasan pelanggan. Metode penelitian dilakukan dalam dalam penelitian tersebut adalah survei cross-sectional dengan jumlah responden sebanyak 369 responden. Lebih lanjut, data yang diperoleh dianalisis dengan menggunakan metode reliabilitas, korelasi dan regresi. Hasil penelitian tersebut menunjukkan bahwa layanan yang ditawarkan oleh unit ritel memiliki dampak positif dan signifikan dalam membangun kepuasan pelanggan. Temuan penelitian empiris tersebut mengulangi pandangan bahwa dimensi Service Quality sangat penting untuk kepuasan pelanggan pada sektor ritel yang sedang berkembang dengan potensi pertumbuhan yang tinggi dan kesempatan dalam pertumbuhan ekonomi cepat seperti di India. ${ }^{13}$

Kemampuan rumah sakit untuk menarik dan mempertahankan pasien baru merupakan sebuah fungsi yang tidak berasal dari produk atau pelayanan itu sendiri, namun juga berkaitan dengan bagaimana organisasi tersebut melayani pasien dan reputasi yang diciptakan oleh rumah sakit, baik di dalam maupun di luar rumah sakit. Mencari pasien baru lebih sulit dan memerlukan biaya lebih mahal dibandingkan bila mempertahankan pasien lama. Loyalitas pasien akan menjadi kunci sukses, tidak hanya dalam jangka pendek, tetapi keunggulan bersaing yang berkelanjutan. ${ }^{14}$ Oleh karena itu, tujuan umum dari penelitian ini untuk mengetahui "pengaruh langsung dan tidak langsung serta besarannya Pencitraan Rumah Sakit, Keputusan Menggunakan Jasa, Kualitas Jasa dan Kepuasan Pasien, terhadap Word of Mouth di RSDH Cianjur Tahun 2015".

\section{Metode}

Penelitian ini adalah penelitian survei yang bersifat analitik dengan desain cross sectional dengan alasan bahwa penelitian ini dilakukan dalam kurun waktu yang bersamaan dan bertujuan untuk menganalisis hubungan kausal antara variabel-variabel melalui pengujian hipotesis yaitu untuk menganalisis pengaruh langsung dan tidak langsung serta besarannya antara Pencitraan Rumah Sakit, Keputusan Menggunakan Jasa, Kualitas Jasa dan Kepuasan Pasien, terhadap word of 
mouth di RSDH Cianjur Tahun 2018.

Populasi adalah kelompok elemen yang lengkap, umumnya berupa orang, obyek, transaksi atau kejadian, dimana peneliti mempelajari atau menjadikannya objek penelitian. Populasi merupakan jumlah keseluruhan dari objek penelitian. ${ }^{15}$ Dalam penelitian ini adalah klien yang bekunjung ke RSDH Cianjur. Teknik sampel yang digunakan dalam penelitian ini adalah Purposive sampling yaitu cara pengambilan sampel berdasarkan kriteria kshusus yang menjadi syarat penelitian. Penentuan sempel ditentukan dari jumlah indikator dikalikan 5-10, jumlah indikator 11, maka ukuran sampelnya adalah sebanyak 55-110. Berdasarkan kedua pertimbangan tersebut maka ukuran sampel dalam penelitian ini ditetapkan 80 responden.

Pencitraan Rumah Sakit diukur dengan menggunakan tiga indikator yaitu pemasaran, brand image dan CSR. Keputusan menggunakan jasa tidak memiliki indikator. Kualitas Jasa memiliki lima indikator yaitu Realibility, Assurance, Tangibel, Empaty dan Responsivness. Kepuasan memiliki tiga indikator yaitu Harapan, cara pelayanan dan Kenyataan Pelayanan.

Kriteria inklusi adalah Klien pemakai jasa RSDH Cianjur dan Bersedia menjadi subjek penelitian atau menjadi responden. Sedangkan kriteria eksklusi untuk sampel adalah Tidak bersedia menjadi subjek penelitian atau menjadi responden pada saat dilakukan pengumpulan data. Analisis deskriptif merupakan analisis kuantitatif yang digunakan untuk menjelaskan lebih mendalam hasil dari analisis dan mampu memberikan informasi yang lebih rinci.

Analisis deskriptif dalam penelitian ini digunakan untuk mengidentifikasi nilai Pencitraan Rumah Sakit, Keputusan Menggunakan Jasa, Kualitas Jasa dan Kepuasan Pasien, dan word of mouth. Serta memaparkan deskripsi variabel penelitian berdasarkan jawaban setiap kuesioner dengan memberikan skor pada masingmasing jawaban. Skala ukur yang dipakai untuk mengukur variabel eksogen dan variabel endogen adalah skala interval dengan menggunakan perbedaan semantik (semantic deferensial) dan skala Likert yang diberi nilai 1 sampai dengan 5

Perancangan pada model pengukuran menentukan sifat indikator dari masingmasing variabel laten, apakah refleksif atau formatif, berdasarkan definisi operasional variabel. Pengolahan data output yang menggunakan bantuan SmartPLS 2.0 disajikan dalam diagram, tabel dan lain-lain agar memudahkan dalam proses membaca dan menganalisis variabal.

Validitas adalah suatu indeks yang menunjukan alat ukur itu benar-benar mengukur apa yang diukur dan juga tepat sasaran dalam pengukurannya. ${ }^{16}$ Analisis deskriptif merupakan analisis kuantitatif yang digunakan untuk menjelaskan lebih mendalam hasil dari analisis dan mampu memberikan informasi yang lebih rinci serta baik dalam segi keakuratan. Analisis multivariat Structural Equation Modeling (SEM). Caranya dengan melihat discriminant validity dengan melihat nilai square root of average variance extracted $(A V E)$. Nilai yang diharapkan di atas 0,50.Uji validitas butir di lakukan dengan aplikasi program SPSS Statistics 18. Reliabilitas adalah indeks yang menunjukan sejauh mana suatu alat pengukur dapat dipercaya atau dapat diandalkan. Hal ini berarti menunjukan sejauh mana hasil pengukuran dua kali atau lebih terhadap gejala yang sama, dengan menggunakan alat ukur yang sama. ${ }^{17}$

Teknik yang di pergunakan dalam uji reliabilitas dengan menggunakan koefisiensi reliabilitas Alpha Cronbach untuk seluruh pengamatan pada variable maupun indikator yang akan dianalis. Suatu instrumen penelitian dikatakan reliabel jika uji reliabilitas kontruk yang diukur dengan dua kriteria yaitu composite reliability dan cronbach alpha dari blok indikator yang mengukur konstruk. Konstruk dinyatakan reliable jika nilai composite reliability maupun cronbach alpha diatas 0.70 .

- Metode analisis yang digunakan 
adalah Structural Equation Model (SEM) mengunakan SmartPLS 2.0 dan SPSS 18. Analisis SEM dengan PLS adapun langkahlangkahnya sebagai berikut, merancang Model Struktural (Inner Model) dengan menggambarkan hubungan antar variabel laten berdasarkan pada substantive theory. Perancangan model struktural hubungan antar variabel laten didasarkan pada rumusan masalah atau hipotesis penelitian dan merancang model pengukuran (Outer Model) atau model pengukuran yang mendefinisikan bagaimana setiap blok indikator berhubungan dengan variabel latennya.

Suatu indikator reflektif dinyatakan valid jika mempunyai loading faktor di atas 0,5 terhadap konstruk yang dituju berdasarkan pada substantive content-nya.

Cara untuk melihat discriminant validity dengan melihat nilai square root of average variance extracted (AVE). Ketentuannya, apabila nilai T-Statistik lebih besar dari nilai $\alpha=0,05 \quad(1,96)$, maka konstruk laten tersebut signifikan terhadap konstruknya. $^{18}$

Penyajian data yang lebih lengkap disajikan dalam lampiran. Penyajian frekuensi dari sampel penelitian data yang disajikan pada awal analisa adalah berupa gambaran atau deskripsi mengenai sampel, dimana penjelasan juga disertai ringkasan berupa tabel dari deskripsi yang utama. Uji coba instrumen di lakukan untuk mengetahui apakah instrumen tersebut valid dan reliabilitas, dengan cara menyebarkan kuesioner pada 80 klien di RSDH Cianjur.

\section{Hasil}

Berdasarkan karakteristik responden dalam penelitian ini, menunjukkan bahwa dari 80 responden sebagian besar kilen $>35$ tahun sebanyak $56(70,0 \%)$ responden. Berdasarkan pendidikan klien memperlihatkan bahwa sebagian besar responden berpendidikan SLTP/ SLTA kebawah yaitu sebanyak $47 \quad(58,8 \%)$ responden. Sedangkan berdasarkan jenis kelamin memperlihatkan bahwa sebagian besar klien berjenis kelamin perempuan sebanyak $51(63,8 \%)$ responden.

Berdasarkan gambar 1, menunjukkan bahwa konstruk Pencitraan Rumah Sakit diukur dengan tiga indikator reflektif yaitu pemasaran, brand image dan Community Social Responsibility (CSR). Kualitas Jasa memiliki lima indikator yaitu Realibility, Assurance, Tangibel, Empaty dan Responsivness. Kepuasan memiliki tiga indikator yaitu Harapan, cara pelayanan dan Kenyataan Pelayanan.

Berdasarkan gambar 1, terlihat bahwa nilai loading factor tertinggi yaitu pengaruh antara pencitraan rumah saki terhadap keputusan menggunakan jasa sebesar 0,705 serta nilai terendah yaitu pengaruh antara kualitas jasa terhadap kepuasan sebesar 0,219 . Berarti indikator yang dipergunakan dalam penelitian ini adalah valid atau telah memenuhi convergent validity. Cara untuk melihat discriminant validity dengan melihat nilai square root of average variance extracted (AVE).

Pada hasil evaluasi AVE pada kontruk Kepuasan sebesar 0,640, Keputusan Menggunakan Jasa 1, 000, media informasi 0,913, Kualitas Jasa 0,665 dan Pencitraan RS 0.795 dinyatakan valid karena nilai AVE di atas 0,5 dengan demikian dapat disimpulkan bahwa evaluasi pengukuran model memiliki discriminat validity yang baik. Didapat nilai cronbach alpha pada semua variabel berkisar 0,700 hingga 1,000 yang berarti semua indikator handal dalam mereflesikan variabelnya harus lebih dari 0,70 (nilai cronbach alpha> 0,70).

Berdasarkan tabel 1, nilai R-Square pencitraan rumah sakit berkontribusi terhadap keputusan menggunakan jasa sebesar 0,497, peran pencitraan rumah sakit dan keputusan menggunakan jasa berkontribusi terhadap kualitas jasa sebesar 0,544, peran pencitraan rumah sakit, keputusan menggunakan jasa dan kualitas jasa berkontribusi terhadap kepuasan sebesar 0,748 , dan peran pencitraan rumah 


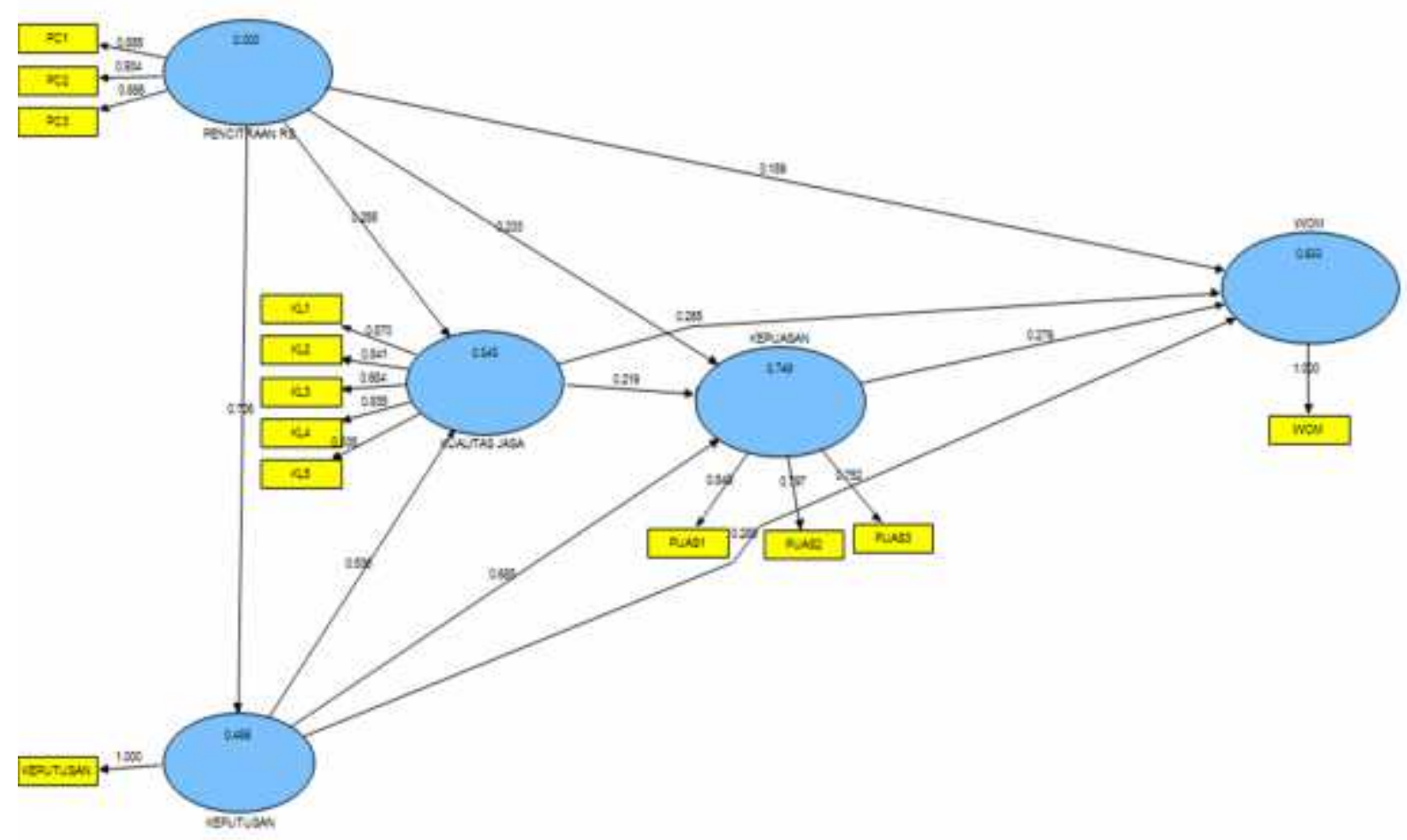

Gambar 1. Output Loading Factor

sakit, keputusan menggunakan jasa dan kualitas jasa dan kepuasan berkontribusi terhadap WOM sebesar 0,833.

Tabel 1. Hasil $\mathrm{x}$ R-Square dari Variabel Pencitraan Rumah Sakit, Keputusan Menggunakan Jasa, Kualitas Jasa dan Kepuasan Pasien, dan Word of Mouth.

\begin{tabular}{ll}
\hline \multicolumn{1}{c}{ Variabel } & $\boldsymbol{R}$-Square \\
\hline Kepuasan & 0,748 \\
Keputusan Menggunakan Jasa & 0,497 \\
WOM & 0,833 \\
Kualitas Jasa & 0,544 \\
\hline
\end{tabular}

Berdasarkan hasil pengukuran tersebut dapat disimpulkan bahwa variabilitas pencitraan rumah sakit berkontribusi terhadap variabilitas keputusan menggunakan jasa sebesar $49,79 \%$ dan $50,21 \%$ dijelaskan oleh variabel lain yang tidak diteliti. Variabilitas peran peran pencitraan rumah sakit dan keputusan menggunakan jasa berkontribusi terhadap kualitas jasa sebesar $54,45 \%$ dan $45,55 \%$ dijelaskan oleh variabel lain yang tidak diteliti. Variabilitas peran pencitraan rumah sakit, keputusan menggunakan jasa dan kualitas jasa berkontribusi terhadap kepuasan sebesar $74,88 \%$ dan $25,12 \%$ dijelaskan oleh variabel lain yang tidak diteliti. Variabilitas peran peran pencitraan rumah sakit, keputusan menggunakan jasa dan kualitas jasa dan kepuasan berkontribusi terhadap WOM sebesar $83,30 \%$ dan $16,7 \%$ dijelaskan oleh variabel lain yang tidak diteliti.

Berdasarkan gambar 2, terlihat bahwa nilai loading factor tertinggi yaitu pengaruh antara pencitraan rumah sakit ke keputusan menggunakan jasa sebesar 6,370 nilai terendah yaitu pengaruh antara pencitraan rumah sakit ke WOM sebesar 1,937. Inner model disebut juga dengan model struktural dapat dievaluasi dengan melihat uji nilai $R$ Square, Hipotesis T-Statistik, pengaruh variabel langsung dan tidak langsung serta Predictive Relevance/Q-square.

Pencitraan rumah sakit berpengaruh positif terhadap keputusan menggunakan jasa, hasil uji menunjukkan ada pengaruh positif 0,705 , sedangkan nilai T-Statistik 


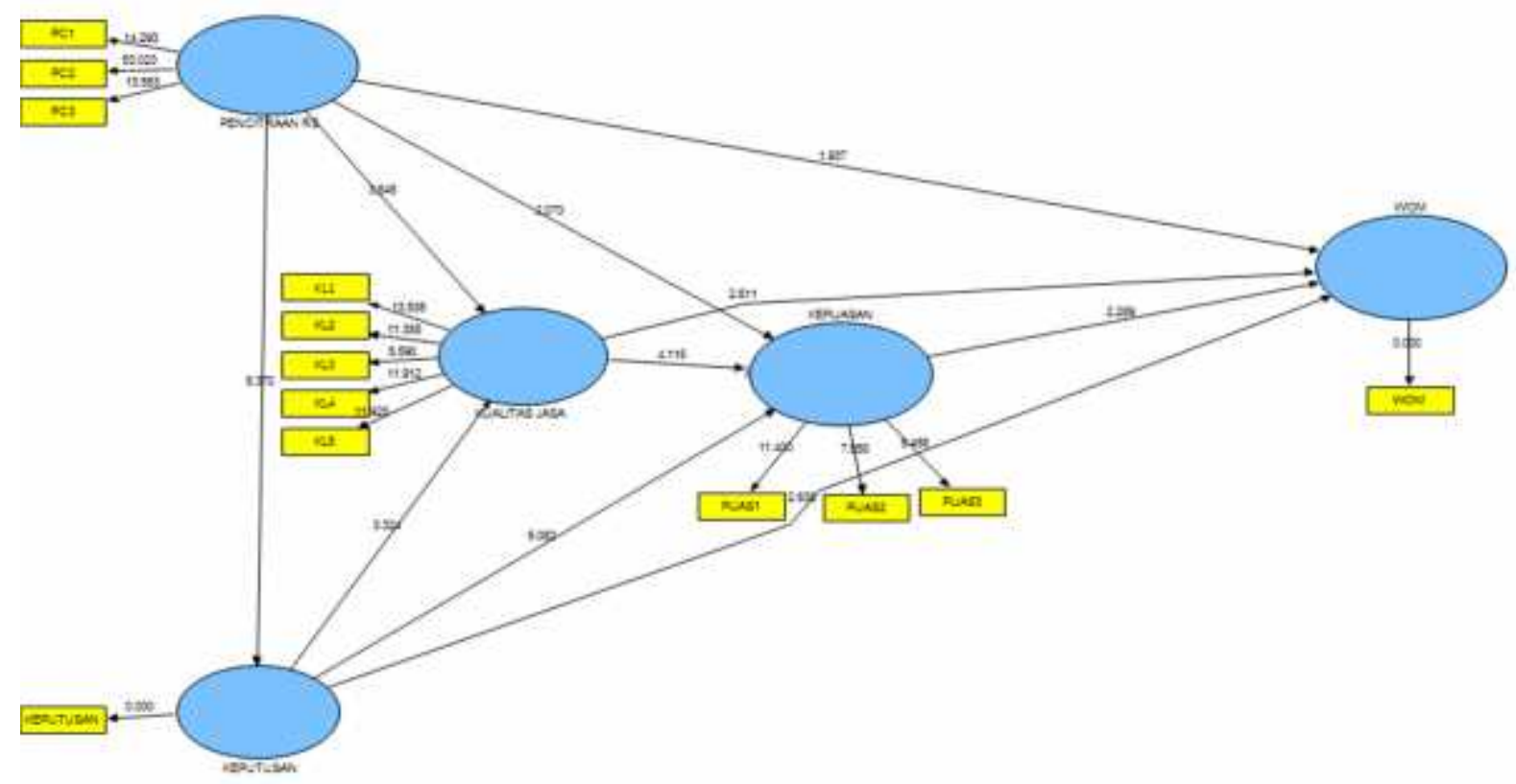

Gambar 2. Output T-Statistik

Tabel 2. Presentase Pengaruh Antar Variabel Terhadap Variabel Word of Mouth Pada Model

\begin{tabular}{|c|c|c|c|c|c|c|c|}
\hline Sumber & $\begin{array}{c}L V \\
\text { Correlation }\end{array}$ & $\begin{array}{l}\text { direct } \\
\text { Path }\end{array}$ & $\begin{array}{c}\text { Inderect } \\
\text { Path }\end{array}$ & Total & $\begin{array}{c}\text { Direct } \\
(\%)\end{array}$ & $\begin{array}{c}\text { Indirect } \\
(\%)\end{array}$ & $\begin{array}{c}\text { Total } \\
(\%)\end{array}$ \\
\hline Pencitraan rumah sakit & 0,758 & 0,221 & 0,537 & 0,758 & 16,73 & 0,72 & 17,45 \\
\hline Keputusan menggunakan jasa & 0,846 & 0,312 & 0,311 & 0,623 & 26,36 & 0,63 & 26,99 \\
\hline Kualitas jasa & 0,795 & 0,158 & 0,085 & 0,243 & 12,58 & 0,19 & 12,78 \\
\hline Kepuasan & 0,852 & 0,309 & & 0,309 & 26,32 & & 26,32 \\
\hline & Total & & & & 81,99 & 1,54 & 83,53 \\
\hline
\end{tabular}

sebesar 6,370 dan signifikan pada $\alpha=5 \%$. Nilai T-Statistik > nilai kritis $(1,96)$. Pencitraan rumah sakit berpengaruh positif ke kualitas jasa, hasil uji menunjukkan ada pengaruh positif 0,632 , sedangkan nilai $\mathrm{T}$ Statistik sebesar 5,891dan signifikan pada $\alpha=5 \%$. Nilai $\mathrm{T}$-Statistik tersebut $>$ nilai kritis (1,96). Pencitraan rumah sakit berpengaruh positif ke kepuasan, hasil uji menunjukkan ada pengaruh positif 0,716, sedangkan nilai T-Statistik sebesar 7,900 dan signifikan pada $\alpha=5 \%$. Nilai TStatistik tersebut > nilai kritis $(1,96)$. Pencitraan rumah sakit berpengaruh positif ke WOM, hasil uji menunjukkan ada pengaruh positif 0,758 , sedangkan nilai $\mathrm{T}$ Statistik sebesar 10,068 dan signifikan pada $\alpha=5 \%$. Nilai T-Statistik tersebut > nilai kritis $(1,96)$.

Keputusan menggunakan jasa berpengaruh positif ke kualitas jasa, hasil uji menunjukkan ada pengaruh positif
0,535, sedangkan nilai T-Statistik sebesar 3,324 dan signifikan pada $\alpha=5 \%$. Nilai TStatistik tersebut $>$ nilai kritis $(1,96)$. Keputusan menggunakan jasa berpengaruh positif terhadap kepuasan, hasil uji menunjukkan ada ke positif 0,685, sedangkan nilai $\mathrm{T}$-Statistik sebesar 6,081 dan signifikan pada $\alpha=5 \%$. Nilai TStatistik tersebut $>$ nilai kritis $(1,96)$. Keputusan menggunakan jasa berpengaruh positif ke WOM, hasil uji menunjukkan ada pengaruh positif 0,618 , sedangkan nilai TStatistik sebesar 4,993 dan signifikan pada $\alpha=5 \%$. Nilai $\mathrm{T}$-Statistik tersebut > nilai kritis $(1,96)$.

Kualitas jasa berpengaruh positif ke kepuasan, hasil uji menunjukkan ada pengaruh positif 0,275 , sedangkan nilai $\mathrm{T}$ Statistik sebesar 4,116 dan signifikan pada $\alpha=5 \%$. Nilai T-Statistik tersebut $>$ nilai kritis $(1,96)$. Kualitas jasa berpengaruh positif ke $W O M$, hasil uji menunjukkan ada 
pengaruh positif 0,265 , sedangkan nilai TStatistik sebesar 2,611 dan signifikan pada $\alpha=5 \%$. Nilai T-Statistik tersebut > nilai kritis $(1,96)$.

Kepuasan berpengaruh positif ke WOM, hasil uji menunjukkan ada pengaruh positif 0,278 , sedangkan nilai T-Statistik sebesar 2,288 dan signifikan pada $\alpha=5 \%$. Nilai T-Statistik tersebut berada di atas nilai kritis $(1,96)$.

Berdasarkan tabel 2, nilai pencitraan rumah sakit berpengaruh secara langsung dan tidak langsung terhadap WOM. Hasil uji koefisien parameter antara pencitraan rumah sakit terhadap WOM didapatkan pengaruh langsung sebesar 16,73\%, sedangkan untuk pengaruh tidak langsung antara pencitraan rumah sakit terhadap WOM melalui keputusan menggunakan jasa, kualitas jasa, maupun kepuasan didapatkan nilai sebesar $0,72 \%$. Keputusan menggunakan jasa berpengaruh secara langsung dan tidak langsung terhadap WOM. Hasil uji koefisien parameter antara keputusan menggunakan jasa terhadap WOM didapatkan pengaruh langsung sebesar 26,36\%, sedangkan untuk pengaruh tidak langsung antara keputusan menggunakan jasa terhadap WOM melalui kualitas jasa dan kepuasan didapatkan nilai sebesar $0,63 \%$.

Kualitas jasa menjadi ukuran baik atau buruknya pelayanan rumah sakit dan berpengaruh secara langsung dan tidak langsung terhadap WOM. Hasil uji koefisien parameter antara kualitas jasa terhadap WOM didapatkan pengaruh langsung sebesar $12,58 \%$, sedangkan untuk pengaruh tidak langsung antara kualitas jasa terhadap WOM melalui kepuasan didapatkan nilai sebesar $0,19 \%$.

Kepuasan berpengaruh secara langsung terhadap WOM. Hasil uji koefisien parameter antara kepuasan terhadap WOM didapatkan pengaruh langsung sebesar 26,32\%Sehingga nilai dari masing-masing pengaruh langsung variabel laten independen tersebut apabila secara bersama-sama menunjukkan kesesuaian dengan nilai $R$ Square atau dengan kata lain hal ini menyatakan bahwa variabel pencitraan rumah sakit, keputusan menggunakan jasa, kualitas jasa, dan kepuasan mampu menjelaskan variabel WOM sebesar $(16,73 \%+26,36 \%+$ $12,58 \%+26,32 \%)=81,99 \%$. Sedangkan pengaruh tidak langsung dari variabel pencitraan rumah sakit, keputusan menggunakan jasa, kualitas jasa, dan kepuasan terhadap variabel WOM sebesar $(0,72 \%+0,63 \%+0,19 \%)=1,54 \%$. Jadi total pengaruh langsung dan tidak langsung sebesar $83,53 \%$.

Nilai $Q$-square menjelaskan bahwa nilai outer model mempunyai 0,9912 atau 99,29\% keragaman data pada variabel Pencitraan Rumah Sakit, Keputusan Menggunakan Jasa, Kualitas Jasa dan Kepuasan Pasien dan konsep mampu mengkaji fenomena yang dipakai dalam penelitian, sedangkan jika model ini diterapkan di tempat lain ada tingkat kesalahan sebesar $0,88 \%$.

\section{Pembahasan}

\section{Pengaruh Antara Variabel Pencitraan Terhadap Word of Mouth di RSDH Cianjur Tahun 2018}

Pencitraan adalah suatu proses sosial yang didalamnya individu dan kelompok mendapatkan apa yang mereka inginkan dengan menciptakan, menawarkan secara bebas mempertukarkan produk yang bernilai kepada pihak lain. ${ }^{18}$ Hasil uji terhadap koefisien parameter antara pencitraan rumah sakit terhadap Word of Mouth menunjukkan menunjukkan terdapat pengaruh langsung sebesar $16,73 \%$, sedangkan untuk pengaruh tidak langsung pencitraan rumah sakit terhadap WOM di RSDH Cianjur melalui kualitas pelayanan dan Kepuasan pasien RSDH Cianjur sebesar $0,72 \%$. Nilai T-Statistik sebesar 10.068 kemudian signifikan pada $\alpha=5 \%$. Nilai T-Statistik tersebut berada jauh diatas nilai kritis $(1,96)$. Berdasarkan hasil uji tersebut dapat dijelaskan bahwa pengaruh langsung pencitraan rumah sakit lebih besar nilainya dibandingkan dengan pengaruh tidak langsung dan signifikan ada 
pengaruh yang positif dari kedua variable tersebut.

Nilai T-statitik menunjukan, bahwa ada pengaruh langsung dan tidak langsung antara pencitraan rumah sakit terhadap word of mouth.

Hasil penelitian ini sependapat dengan riset Setyawati, yang menunjukan bahwa bauran pemasaran produk, harga, tempat, promosi, orang, proses, serta bukti fisik mempunyai pengaruh terhadap rekomendasi, baik secara perorangan maupun secara serempak. Dalam peneltian tersebut juga direkomendasikan kepada pihak manajemen rumah sakit untuk mengoptimalkan kualitas dan profesionalisme karyawan agar memberikan pelayanan yang berfokus terhadap kebutuhan pasien sehingga mampu memberikan pelayanan sempurna maka pasien akan merasa puas dan selanjutnya akan merekomendasikan kepada orang lain. ${ }^{19}$

Peneliti membahas bahwa pencitraan rumah sakit rumah sakit perlu ditingkatkan, sehingga pemahaman calon pasien mengenai RSDH akan semakin baik dan menumbuhkan rasa kepercayaan, jika rasa keercayaan sudah terbentuk pada pasien maka dapat meningkatkan jumlah kunjungan pasien dan menjaga kelangsungan hidup RSDH Cianjur berjalan dengan baik.

\section{Pengaruh Antara Variabel Keputusan Menggunakan Jasa Terhadap Word of Mouth di RSDH Cianjur}

Pengambilan keputusan adalah proses memilih alternatif cara bertindak dengan metode yang efisien sesuai kondisi yang ada. Ketika keputusan sudah dibuat, sesuatu yang baru mulai terjadi. Dengan kata lain, keputusan mempercepat diambil tindakan, serta mendorong lahirnya gerakan dan perubahan ${ }^{19}$

Keputusan menggunakan jasa berpengaruh secara langsung dan tidak langsung terhadap word of mouth. Hasil uji koefisien parameter antara Keputusan menggunakan jasa terhadap word of mouth didapatkan pengaruh langsung sebesar 26,36\%. Nilai T-Statistik sebesar 4,993 dan signifikan pada $\alpha=5 \%$. Nilai TStatistik tersebut berada jauh diatas nilai kritis $(1,96)$. Berdasarkan hasil uji tersebut dapat dijelaskan bahwa pengaruh langsung penjualan keputusan menggunakan jasa lebih besar nilainya dibandingkan dengan pengaruh tidak langsung dan signifikan ada pengaruh yang positif dari kedua variable tersebut. Nilai T-statitik menunjukan, bahwa ada pengaruh langsung dan tidak langsung antara penjualan keputusan menggunakan jasa terhadap word of mouth.

Penelitian Sari, menyatakan bahwa ada hubungan antara keputusan menggunakan jasa dengan word of mouth dalam pemanfaatan ulang pelayanan kesehatan pada praktek dokter keluarga di Klinik Sayung Husada dengan $\mathrm{P}$ Value 0.000. Dari hasil penelitian tersebut menunjukan bahwa persetujuan kedua belah pihak antara penjual dan pembeli, dimana penjual menawarkan suatu produk maka pembeli akan memilih dan membandingkan barulah kemudian melakukan pengambilan keputusan dengan harapan pembeli dapat memberikan sejumlah uang sebagai alat tukar produk tersebut, sebesar harga jual yang disepakati. ${ }^{20}$

Penulis berpendapat bahwa proses pengambilan keputusan dan pemilihan penggunaan pelayanan di RSDH Cianjur dapat ditingkatkan dengan terus memberikan promosi serta memberikan pelayanan rumah sakit yang meliputi melaksanakan kegiatan pelayanan kesehatan promotif dan preventif bagi kesehatan pasien, staf rumah sakit serta masyarakat di wilayah cakupannya yaitu di kabupaten Cianjur dan sekitarnya, serta pengembangan rumah sakit menjadi organisasi yang sehat. Hal tersebut dapat mendorong kepercayaan pasien dalam mengambil keputusan menggunkan jasa di RSDH Cianjur sehingga memberikan kontribusi besar terhadap keberlangsungan rumah sakit. 


\section{Pengaruh Antara Variabel Kualitas Pelayanan Terhadap Word of mouth di RSDH Cianjur}

Kualitas produk (baik barang ataupun pelayanan) berkontribusi besar pada kepuasan pelanggan, retensi pelanggan, word of mouth, pembelian ulang, loyalitas pelanggan, pangsa pasar dan profitabilitas

Hasil uji terhadap koefisien parameter antara Kualitas Pelayanan Terhadap Word of mouth menunjukkan terdapat pengaruh langsung sebesar 12,58\%. Nilai T-Statistik sebesar 2,611 dan signifikan pada $\alpha=5 \%$. Nilai T-Statistik tersebut berada jauh diatas nilai kritis $(1,96)$. Hasil penelitian menunjukkan, terdapat pengaruh yang positif dari kualitas pelayanan terhadap word of mouth.

Hasil penelitian ini sejalan dengan penelitian oleh Utami, bahwa faktor utama yang mempengaruhi kualitas jasa, menurut Parasuraman yaitu expected service dan perceived service. Apabila jasa yang diterima atau dirasakan (perceived service) sesuai dengan yang diharapkan, maka kualitas jasa dipersepsikan baik dan memuaskan. Jika jasa yang diterima melampaui harapan pelanggan, maka kualitas jasa yang dipersepsikan sebagai kualitas yang ideal. Sebaliknya jika jasa yang diterima lebih rendah daripada yang diharapkan, maka kualitas jasa dipersepsikan buruk. Dengan demikian baik tidaknya kualitas jasa tergantung pada kualitas pelayanan penyedia jasa dalam memenuhi harapan pelanggannya secara konsisten. ${ }^{21}$

Oleh karena itu peneliti menganalisis bahwa kualitas pelayanan yang diberikan rumah sakit kepada klien (pasien) mungkin secara teknik telah mencakup standar kualitas yang tinggi, tapi apabila pasien berpendapat bahwa pelayanan yang diberikan tidak berkualitas, maka hal itu menjadi tidak ada gunanya. Faktor lain yang tidak diteliti dapat mempengaruhi word of mouth di RSDH Cianjur selain pencitraan rumah sakit, keputusan menggunakan jasa, kepuasan pasien dan kualitas pelayanan adalah salah satunya kompetisi rumah sakit swasta dan rumah sakit pemerintah, faktor jarak yang ditempuh dari rumah pasien ke lokasi rumah sakit dan fasilitas yang tersedia di RSDH Cianjur dibandingkan rumah sakit lain.

\section{Pengaruh Antara Variabel Kepuasan pasien Terhadap Word of mouth di RSDH Cianjur}

Kepuasan pelanggan adalah sejauh mana ekspektasi pelanggan setuju dengan kinerja aktual dari produk dan atau jasa. Hasil uji terhadap koefisien parameter antara Kepuasan pasien Terhadap word of mouth menunjukkan terdapat pengaruh langsung dengan nilai sebesar 26,32\%. TStatistik signifikan sebesar 2.288 pada $\alpha=5 \%$. Nilai T-Statistik tersebut berada jauh diatas nilai kritis $(1,96)$. Berdasarkan hasil uji tersebut bahwa pengaruh yang positif dari kepuasan pasien terhadap word of mouth. Sehingga apabila Kepuasan pasien ditingkatkan maka dapat meningkatkan pula word of mouth secara langsung, begitupun sebaliknya apabila kepuasan pasien rendah dapat menurunkan word of mouth secara langsung.

Hasil penelitian ini sejalan dengan penelitian Yuriansyah, menyatakan bahwa kepuasan pasien dipengaruhi langsung oleh harga, ketepatan pelayanan dan rasa aman. Hasil ini juga mendukung pendapat Engel dalam Tjiptono menyatakan bahwa kepuasan pelanggan merupaka evaluasi purna beli di mana alternatip yang di pilih sekurang - kurangnya sama atau melampaui harapan pelanggan ,ketidak puasan muncul apabila hasil tidak memenuhi harapan. Sedangkan menurut Kotler kepuasan pelanggan adalah tingkat perasaan seseorang setelah membandingkan kepuasan atau hasil yang ia rasakan dengan harapannya. ${ }^{22}$

Oleh karena itu peneliti berpendapat bahwa kepuasan pasien mutlak harus dilakukan oleh RSDH Cianjur, untuk memberikan kepuasan pada pasien maka perlu mengoptimalkan, menjaga dan terus 
meningatkan kualitas atau mutu RSDH Cianjur, sehingga memiliki hubungan yang sangat erat dengan kepuasan pelanggan, yaitu kualitas memberikan suatu dorongan kepada pelanggan untuk menjalani ikatan hubungan yang kuat dengan RSDH Cianjur. Dalam jangka panjang ikatan seperti ini memungkinkan RSDH Cianjur untuk memahami dengan saksama harapan pelanggan serta kebutuhan mereka.

\section{Kesimpulan}

Hasil penelitian menunjukan bahwa variabel word of mouth di RSDH Cianjur dipengaruhi oleh pencitraan rumah sakit $(16.73 \%)$, keputusan menggunakan jasa (26.36\%), kualitas pelayanan $(12.58 \%)$ dan kepuasan pasien (26.32\%). Pengaruh langsung word of mouth di RSDH Cianjur sebesar $81.99 \%$ dan pengaruh tidak langsung sebesar $1.54 \%$. Total pengaruh langsung dan tidak langsung word of mouth sebesar $83.53 \%$.

Keputusan menggunakan jasa dari pasien merupakan faktor yang dominan yang sangat mempengaruhi word of mouth di RSDH Cianjur dan jika dapat meingkatkan kepercayaan maka pasien akan memutuskan menggunakan jasa yang diberikan oleh RSDH Cianjur, maka akan word of mouth di RSDH Cianjur akan meningkat secara positif. Sebaliknya jika keputusan menggunakan jasa dari pasien kurang atau sedikit, maka word of mouth di RSDH Cianjur juga akan menurun.

\section{Saran}

Dari segi pencitraan rumah sakit, sebaiknya bagi marketing RSDH Cianjur perlu meningkatkan promosi jenis pelayanan utama tentu dengan memperhatikan kode etik periklanan rumah sakit. Promosi pelayanan kesehatan perlu dilakukan ditingkatkan melalui media massa seperti televisi, radio dan brosur, mengingat promosi merupakan indikator pencitraan rumah sakit yang paling berpengaruh terhadap peningkatan word of mouth.

\section{Daftar Pustaka}

1. Abdolvand, Mohammad, Ali., dan Norouzi, Abdollah. The Effect of Customer Perceived Value on Word of Mouth and Loyalty in B-2-B Marketing. Journal of Applied Sciences, Engineering and Technology, Vol. 4(23): 49734978; 2012.

2. Assauri, Sofyan, (2004) Manajemen Pemasaran ( Dasar, Konsep dan Strategi ), Jakarta , Penerbit PT. Grafindo Persada, 2010.

3. Anton, J, Listening to the Voice of the Customer: 16 Steps to a Successful Customer Satisfaction Measurement Program, The Customer Service Group. New York, NY; 1997

4. Jay H. Baker, "Customer Satisfaction and Word Of Mouth," Journal of Research, 1 Aug 2016, (dalam Lovelock,2001:299): 2016

5. Choi, Eun, Jung., dan Kim, Soo-Hyun.. The Study of the Impact of Perceived Quality and Value of Social Enterprises on Customer Satisfaction and Re-Purchase Intention. Journal of Smart Home. Vol. 7, No.1; 2013

6. E. J. Choi, S. Kim and L. Choi, The Exploratory Study for Consumers' Associations towards Social Enterprises and Social Enterprises' Products", Korea Marketing Conference, Korean Marketing Association, Seoul, Korea, 2012.

7. Ghalandari, K., The Effect of Perceived Justice Dimensions on Satisfaction, Perceived Quality and Trust as Factors Influencing Loyalty in a Situation of Failure Recovery in Retail. Life Science Journal, 10 (3s): 256-564; 2013.

8. Ghozali, I. dan Fuad.. Model Persamaan Struktural, Konsep dan Aplikasi Dengan Prgram AMOS, Semarang.Vrsi 5. Universitas Diponegoro: 2005.

9. Hananing, Putriadi Rahma, Analisa Pengaruh Kualitas Layanan terhadap Word Of Mouth pada Lembaga Pendidikan English First Semarang, Universitas Diponegoro; 2011.

10. Hanzaee, Kambiz, Heidarzadeh., Bigdeli, Fariba., Khanzadeh, Mahmoud., dan Javanbakht, Arezu; 2012.

11. Harsasi, Meirani. Word of Mouth dalam Industri Jasa Kaitannya dengan Sikap dan Kemungkianan Membeli. Jurnal Bisnis Strategis. Vol 15 No.1; 2006.

12. Khan, Nasreen., dan Kadir, Sharifah, Latifah, Syed A.. The impact of perceived value dimension on satisfaction and behavior intention: Young-adult consumers in banking industry. Journal of Business Management Vol.5 (11), pp. 4087-4099; 2011

13. Chengiz, Ekrem., dan Yayla, Hilmi, Erdogan. The effect of marketing mix on positive word of mouth communication: evidence from accounting offices in Turkey. Journal of Innovative Marketing. Vol. 3; 2007 
14. Kotler, Phiplip. dan Keller, Kevin, Lane. Manajemen Pemasaran, Edisi 13 Jilid 1 \& 2. Jakarta, Erlangga: 2009

15. Maharani, Astri Diah, Analisa Pengaruh Kepercayaan dan Kepuasan Terhadap Loyalitas Nasabah Tabungan Bank Mega, Semarang; 2010

16. Maima, Riska KH, Analisa Pengaruh Kepercayaan Pelanggan dan Kualitas pelayanan Terhadap Sikap Pelanggan dan Implikasinya terhadap Keputusan Membeli Ulang, Skripsi Semarang: Universitas Diponegoro; 2012

17. Nasution, M Nur,. Manajemen Jasa Terpadu. Bogor: Ghalia Indonesia; 2004

18. Ozcan, Kerimcan and Venkatram Ramaswamy, "Word-of-Mouth: A Critical Review, Synthesis, and Research Agenda"; 2008

19. Setyawati, Indah, Analisis Pengaruh Kualitas Layanan dan Kepuasan Pasien Terhadap Word of Mouth (Studi Pada Pasien Rawat Jalan RS. Bhakti Wira Tamtama Semarang). Tesis, Semarang: Universitas Diponegoro; 2009

20.Sari, R Pengaruh Kualitas Produk,Persepsi, Harga, dan Word of Mouth Communication Terhadap Keputusan Pembelian Semarang CV. Mega Jaya Mebel; 2012

21. Utami S.U, (2009) Analisis faktor-faktor yang mempengaruhi kepuasan konsumen dalam mempergunakan jasa transportasi PT. Solo Central Taxi di Surakarta, Jurnal Ekonomi dan Kewirausahaan Vol. 9, No. 1, April 2009 : 33 44, Surakarta, Fakultas Ekonomi Universitas Slamet Riyadi; 2009

22. Yuriansyah, Auli, Lucky. Persepsi Tentang Kualitas Pelayanan, Nilai Produk Dan Fasilitas Terhadap Kepuasan Pelanggan. Journal of Management Analysis; 2013. 